\title{
KOMUNIKASI SIARAN INTEGRASI MEDIA KONVENSIONAL DAN INTERNET PADA PENYIARAN RADIO SWASTA
}

\author{
Harliantara \\ Program Studi Ilmu Komunikasi, Universitas Sangga Buana
}

\begin{abstract}
Abstrak
Penyiaran radio adalah media elektronik tertua, hampir satu abad lebih keberadaannya dan berusaha untuk tetap eksis mengatasi persaingan keras dengan hadirnya media-media lain. Saat ini, mulai muncul teknologi baru dan metode distribusi yang memiliki efek mendalam pada cara di mana khalayak mendengarkan penyiaran radio melalui media internet. Dalam proses komunikasi siaran radio, lembaga penyiaran radio konvensional terjadi penambahan media yaitu internet. Penelitian ini menggunakan pendekatan kualitatif untuk mengkaji komunikasi siaran integrasi media radio konvensional dan internet pada penyiaran radio swasta. Data dikumpulkan melalui observasi lapangan, wawancara, dan studi dokumentasi. Hasil penelitian ini menemukan bahwa pemaknaan proses komunikasi siaran integrasi media radio konvensional dan internet sebagai konvergensi media menjadi krusial untuk meningkatkan pengetahuan penyiaran radio di masa kini dan masa yang akan datang. Selain itu, penelitian ini menemukan bahwa selain transmisi melalui udara atau (broadcast) dalam bentuk suara atau bunyi, penyiaran radio saat ini juga melakukan live streaming atau podcast streaming melalui internet (network) dalam bentuk suara, teks, gambar maupun video.
\end{abstract}

Kata kunci: Radio Konvensional, Internet, Integrasi Media

\begin{abstract}
Radio broadcasting is the oldest electronic media. The rising of contemporary new media had a profound effect on radio broadcasting. Radio broadcasting institutions began to use internet technology in their distribution of information. This study used a qualitative approach to study the integration of radio conventional technologies and new media in private radio broadcasting context. Data were gathered through observation, interviews, and documentation. The research found that the meaning of the integration of conventional radio technologies and new media is part of media convergence and crucial to improving knowledge on radio broadcasting in the present and future. Radio broadcasting now does not only transmit a sound or voice through the air (broadcast) but also transmit text, pictures, and video by live streaming or podcasts streamed through the Internet (network).
\end{abstract}

Keywords: Conventional Radio, Internet, Media Integration 


\section{INTRODUCTION}

Private radio broadcasting in Indonesia continues to grow and make improvements in distributing its broadcast messages both conventional channels spectrum of electromagnetic frequencies and also modern channel internet. In this case, radio broadcasting utilizes technological innovation communication which broadcasted in the internet with streaming on the website. The listeners can listen through radio frequency receiver, and the internet streaming (Keith, 2007:314). Through internet, audio and video information is delivered in real time. The listeners can access to see, hear or download music content and podcasting. The files can be downloaded online in the form of audio and video and provide a wide range of visual data, such as images, text, and networking (Mirabito, and, Morgenstern, 2004:215)

Exploring the changing concept of broadcast communications conventional radio from the broadcasting radio industry perspective developed the implementation recently is a phenomenon in the management of each radio broadcasting by its anticipation to the computer era, digital and internet radio device which integrated on conventional radio. The convergence theory explains that communication model represents a process rather than a single action, share or exchange more than one mode of transmission, two or more participants in the dialogue, for the confusion of clarification between information, knowledge, messages, symbols and meanings, as well as the self-correcting feedback process and series which allows to reach the goal dynamically. One of the causes of convergence media are technical problems, due to more media content included in digital format with the form of bits (Littlejohn and Foss, 2009:188)

There is a change in technology, textual, conventional and culture. Some of the key terms in the discourse about this new media is digital which allows to understand some of the operations involved in the production of text to the number of symbol and interactivity (Lister, et al., 2009:18). The changes in empirical perspective could be the real example of the dynamics in radio management at the present era. When the values of the internet has been entered to minds and thoughts of radio broadcasting organizer research, is needed to be able to uncover the occurrence phenomenon. This study intends to provide in-depth picture of broadcast communications integration conventional media and the internet in private radio broadcasting. The research aims to gain factual knowledge in articulating broadcast communications integration of conventional media and the internet private radio broadcasting related to broadcasting. This study expected to obtain clear and objective picture of how and why communication conventional broadcast and internet media integrated on private radio broadcasting.

The purpose of this study was formulated and stated to the principal question:

How do broadcast communications integration of conventional media and the internet communicate on private radio broadcasters?

The media is nothing but a tool to reinforce, strengthen and expand human feeling functionality. In other words, each 
new media discovery has to be considered to extend human abilities and skills. There are some major changes that follow the developments in communications technology following this theory, where each period is equally expanding human feelings and thoughts.

When people in the world think about the media, they mostly use their leisure time activities in the world are watching television. But, there are many forms of media which should be studied in mass communication. Until now, defining the mass media communication is easy (Littlejohn and Foss, 2009:623). The theory of mass communication has also evolved with the changing nature of media. Although the definition of communication may vary from source to source, the definition has the same elements. Mass communication is often depicted or described by comparing interpersonal communication, when the source encodes the message and sends it to the receiver through verbal and nonverbal. Then, the message is decoded the message and provided feedback.

In interpersonal communication, source and receiver are usually individual. It is face-to-face channels, and the communication is usually private. Feedback is generally directly and immediately. However, mass communication, is the process by which a group of people, or large organizations create and send a message to the audience at some kind of heterogeneous media. With the internet-designed channel unique content showcase, the listeners become relatively small.

It should keep in mind that the process of becoming a basic medium of radio broadcasting can be used for personal communication and mass communication. As we know that the success of any communication is determined by the behavior of listeners' response. The response is usually a reaction from listeners due to the attention of symbols on the radio, which is listening to the radio. Even before the audience listening, a program should be heard through the radio receiver.

The listeners listen to the radio broadcast can be called a response. Another type of response is the reception symbol through radio programs lead to affective communication behavior in public, such as laughing, crying, shaking or any kind of it. The important role of mass communication is the basis of radio broadcasting as media rather than comparing to other communication which only transmitting the messages. In mass communication, however, the transmission is very complicated to be solved by an individual or even a few people. It is because the transmission involves the distribution of matter and presentation of the material. One of the distinctive characteristics of radio broadcasting as a medium is a personal medium (Turow, 2009:13).

Radio broadcasting is an arena of fantasy, a theater in our minds, with unlimited number of performances created from words and images that we imagined (Schulberg in Prayudha and Munaf, 2013:5). As with other conventional media, radio is a medium that has range of selective towards particular market segment. The terms of radio in this description is not the object, nor the only physical form, but also between physical and radio activities are intertwined cannot be separated from one another, as well as human body and soul that cannot be separated. Therefore, if the 
radio understanding is defined separated one by one or itemized physically. It defined as the whole transmitter, studio, and receiver. Because there is no literary description when the radio is full of creativity run by such programs, the radio can immediately attracted the interest of many people (Schulberg, 1996:5). Radio broadcasting is unique, grows, and becomes pervasive medium. The form of unique here is to have the ability to send electronic advertising messages according to geographically and demographically (Weinberger, et al., 1994:1).

Basically, the communication process is the equation of knowledge, experience, and taste, among individuals or groups. In the process of communication through medium of radio, the backflow cannot be flown directly, but it delayed (Wahyudi, 1994:4). This pending flow is the concern of radio broadcasting operators to enhance the broadcast program. In the world of broadcasting, business for the benefit of the audience begins to draw the attention of listeners, so they are willing to listen to the radio broadcast. Radio is a very valuable advertising medium to set goals and achieve big and small opportunities needed by the advertiser. (Weinberger, et al., 1994:10)

Rapid change and convergence of information and communication technologies has sparked the cultural change, social, and economic. The information technology of global communication increased in its capacity and developed an interactive and dynamic operation to the factor in the level of competitiveness of industrial enterprises, both nationally and internationally.

It would not be achieved without the effectiveness of technology development in achieving a high level of cultural, social, economic and technological development. It is strongly influenced by the adoption of technology and information (Yunis, 2010:256). The elements that affect business environment are in digital environment and global environment. They should be the impetus for individuals, organizations, and governments in establishing an effective plan to take the opportunities, challenges and become more competitive (Friedman in Yunis, Manal M., 2010). The ability of information and communication technology (ICT) is considered as an important factor to achieve economic development and innovation (McKelvey in Yunis, 2010). Information and communication technology (ICT) has a broad sense, but basically it includes digital equipment such as computers and applications that drive the equipment as well as basic infrastructure internet, extranet, and intranet (Dewulf and Meel., 2002:242). Therefore, radio broadcasters must quickly respond to these changes by developing the leading and creative radio management. Broadcast radio management situation is different from the presence of internet as a new medium of communication technology and previously it requires different management practices. Advances in technology not only have result the introduction of alternative types of broadcasting but also alternative new media to listen to the radio. (Fleming, 2002:10)

The media made the relationship between production and audience in a variety of ways at this time. This relationship depends on the technology. From this technology, it will shape society and the cause of social change. As a result 
of today's media continues to innovate in anticipating changes in technology. The media development continues to be a locomotive change (Burton, 2005:198). Changes is increasingly being the evident when many private radio broadcasters in Indonesia, especially in Bandung, deliver broadcast messages not only through two conventional media (AM \& FM waves), but also they added internet radio broadcasting media services. Almost all current conventional media use internet to present their products.

In 2oth century, the new information technologies have the potential to affect people's lives and business, education, and government (Brynin, and Kiesler, 2006:3). The new technology utilized to facilitate the globalization, since its capacity to overcome the barriers of space and time (including national boundaries) for communication. Therefore, the radio broadcast will be changed by the presence of media communications technology because its coverage is not limited by space and time (McQuail, 2000:136). Changes in the Internet is very clearly seen by anyone, which is initially applied at the static web pages for later dynamic content that can be shared and appeared in social networks. Internet is no longer just a place to look for information, but it is now a forum for collaborating, a place to create, and share online content. The most popular places on the internet nowadays mostly are social media. It has also changed the way of human life.

Today, almost all radio broadcasters have created websites to promote their radio broadcasting, providing news and the information as well. The music program broadcast on the air through internet. Internet radio provides voice, text, graphics, and video to meet various needs of listeners on the internet (Medoff and Kaye, 2011:80). By spreading of information through the internet, every individual, company, or organization can take the advantages from online media such as websites and social media. They are now highly prioritized by most people. Internet technology also has advantages, including: target specific consumer, special messages, interactive capabilities, access to information, creativity, extensive exposure, and speed (Vivian, 2008:266)

The fastest internet worldwide technology utilizes network communication protocol TCP-IP (Transmission Control Protocol / Internet Protocol) and provides excellent prospects for the radio broadcast industry. Through the internet, a lot of radio stations broadcasting throughout the world, including Indonesia, has been providing broadcast reception facilities in the form of multimedia information to the public. The internet can be accessed through personal computer and also be a mobile phone (Sunaryo, 2013:78). Technology radio broadcasts through internet or commonly referred to as online at the level of implementation. It is based on the technology of encoding and delivery of streaming. Internet audio, sometimes supplemented by streaming video through the websites of the radio website. Basically, radio technology can make the website add audio, video, images, and text with simple process of data processing.

This new era has the impact to media environment that changing rapidly. Just a few years ago, most people have never heard about multimedia or internet. Changes in media environment are many kinds of. The term of convergent is known 
as merging separate services, including Internet, television, radio, cable, and phone.

It is happened because media convergence is a technical problem. Not all media content are included to the digital format. One of the dominant trends in electronic media in the last 20 years is convergence. Convergence also refers to the blurring of the boundaries between various types of electronic communications media, such as voice note and online services that traditionally have different function. By using different methods and associated platforms with the listeners on radio, telephone, and computer. Moreover, it can use a variety of media at the same time. In other words, when connected to the internet through broadband connection, some activities can be done by listeners such as listening to online radio stations, retrieving emails, listen to music, download, or use instant messaging to conduct conversations (including audio and video) with those in the same time all over the world. By using a smart phone (iPhone or Blackberry), the listeners can receive calls, send and receive text messages, digital pictures and video, store and play MP3 music files and surf the web. Digitization has also changed the way we read books. Obviously, digitalization and convergence have omitted the lines that distinguish one media to the other media. So, the definition of traditional media is needed to be reevaluated.

The convergence is a general term that refers to the new textual practices, branding and marketing strategies, industry regulation, synergy of technology, and audience behavior activated and driven by the advent of digital media. (Lawson, 2008:3) Convergence is a term that is difficult to understand because it is used in several contexts and often puzzled in giving the definition. Convergence from journalistic perspective is the practice of journalism and sharing a variety of media content, interactive, through collaboration and partnerships newsroom. According to Wirtz (1999), the definition that focuses on multimedia applications, stated that convergence can be defined as a dynamic approach or partial integration of different communication and information-based applications. Further aspects of convergence is that the convergence brings additional products and services to customer satisfaction and some integrated multimedia (Littlejohn and Foss, 2009:625)

\section{RESEARCH METHODOLOGY}

The research found that the broadcast communication integration of conventional media and the internet in private radio broadcasting with the essential components. These findings are consistent with the intent to provide indepth picture of the broadcast communications integration of conventional media and the internet on private radio broadcastings. In addition it aims to acquire factual knowledge that reveals broadcast communications integration of conventional media and the internet in private radio broadcasting. The other thing is to develop concepts, theoretical models, and broadcast communications approach integration of conventional media and the internet in private radio broadcasting.

This study uses qualitative data analysis with the approach of case study. The method of qualitative data analyses in the case of broadcast communication that 
emphasizing the integration of conventional media and the internet on private radio broadcasting. It directed to collect and analyze flexible data to gain an understanding of the case. The results of this study were explained from the standpoint of conventional media integration broadcast communications and internet on private radio broadcastings.

The object of this study is broadcast communications integration of conventional media and the internet on private radio broadcasting. The subject was Radio Lintas Kontinental (K-LITE FM Bandung). The researcher selected informants who know about the implementation of radio broadcasting. The determination of informants was done purposively, which chosen by consideration and specific purposes. The informants should have special characteristic in private radio broadcasting institutions, namely PT. Radio Lintas Kontinental. The researcher conducted a study in PT. Radio Lintas Kontinental which is located at Jalan Sumur Bandung No. 12 Bandung.

The researcher chose PT. Radio Lintas Kontinental (K-LITE FM) because it has characteristics of music and information held by the group of YPT (Telkom Education Foundation). The implications on the data and analysis of radio broadcasting institution are professionally managed and have implemented radio broadcasting through internet. While the time and the period of the study was conducted from January 2013 to July 2014 (Compilation of research planning, pre-research, field research, processing and analysis of data, preparation of reports)
The researcher has collected data through interviews, observed by the means of visiting the study site, listening to the radio broadcast on air and live streaming, observing and studying the radio's website and search for documentation. The researcher used qualitative interviewing in conducting the interviews. It is kind of field research with more active investigation. The resource of radio broadcasting operators has been prepared in conducting interviews.

In the interviews, their answers are recorded based on a range of topics covered in depth questions. The researcher also did the observation in the field that are connected with the research problem and assume the values with methodological steps. In addition, the researcher also collected and reviewed the written data related to the research problem both from source documents, books, journals, magazines, internet, and others. The data analysis was performed using qualitative data analysis. The data obtained from various sources by using triangulation of data collection techniques. Additionally, the data processing organized, analyzed, and explained the pattern description communication between the dimensions of conventional broadcast and internet media integration on private radio broadcasting.

The researcher conducted a study with a framework related to the case study using the technique of analysis data reduction, data display, and conclusion. The researcher conducted four test data validity to be assured. Therefore, the validity of the research results was conducted through:

1. Credibility. The researcher conducted observations in broadcast 
communications integration of conventional media and the internet in radio broadcasting. Besides that, the researcher conducted interviews with informants and continuous observation.

2. Triangulation. The researcher conducted data analysis with data collection and data sources that already re-examined back. The researcher discussed with radio communications expert and an expert on broadcast communication management integration of conventional media and the internet in radio broadcasting. In this study, the researcher used a tool like voice recording the laptop with a cool app to edit note applications, record, and smart phone cameras (Black Berry and Samsung Galaxy Note II).

3. Transferability, the research result can be applied by other researcher, especially in the field of radio communications and broadcasting. The researcher also hopes that these results can be understood by the reader.

4. Dependability. It holds an audit trial form of communication with the communication expert and radio broadcasting in discussing cases relating to the broadcast communication of data integration on conventional media and the internet in private radio broadcasting.

\section{RESULTS AND DISCUSSION}

The implementation of radio broadcasting communication utilized part of the electromagnetic spectrum to transmit signals. Radio broadcasters are required to pay the cost of the spectrum. The research found that PT. Radio Lintas Kontinental (K-LITE FM Bandung) each year shall pay dues to the Minister of Communication and Information of the Republic of Indonesia for the purposes of broadcast licenses (IPP) and the Ministry of Posts and Telecommunications of the Republic of Indonesia to the spectrum or Radio Station Permission (ISR).

The electromagnetic spectrum consists of low-frequency radio waves and high frequency cosmic rays. This technology brings the transmission of electromagnetic waves (radio frequency). The implementation of a radio broadcast requires transmitter that has a function to generate and establish appropriate radio waves with frequencies of radio broadcasters that have been set by government. PT. Radio Radio Lintas Kontinental (K-LITE FM Bandung) obtain 107.1 MHz frequency. The sound sent from the broadcast studio to the transmitter, and then the transmitter sends a radio receiver to convert into sound waves. Thus, the technology used by conventional radio broadcasting is the electromagnetic wave spectrum.

The technological developments through radio broadcasting electromagnetic waves (conventional) began to be integrated through the internet in the early 2000s in America. Radio broadcasting began to be accessed through internet, but not all conventional radio broadcast distributes its streaming on the internet. The excess of streaming is all radio broadcasts can be accessed and enjoyed through computer by the listeners. In Indonesia, according to the observations of researcher has its internet radio trend that began around 2008. The developer of computer software makes the streaming radio services from conventional radio from broadcasters that already integrated through the internet 
and radio broadcasts, and made by individuals.

Along with the change in the paradigm of radio broadcasting in the internet media era, it was found that PT. Radio Radio Lintas Kontinental (K-LITE FM Bandung) adjusted to innovate, where the product is not only radio broadcast distributed through conventional media services (frequency), it has also added with radio broadcasting services through online radio. In this condition, radio broadcasting distributes the products with the incorporation of radio broadcasting services (co-exist), which is a service of conventional media and internet media services to the listeners.

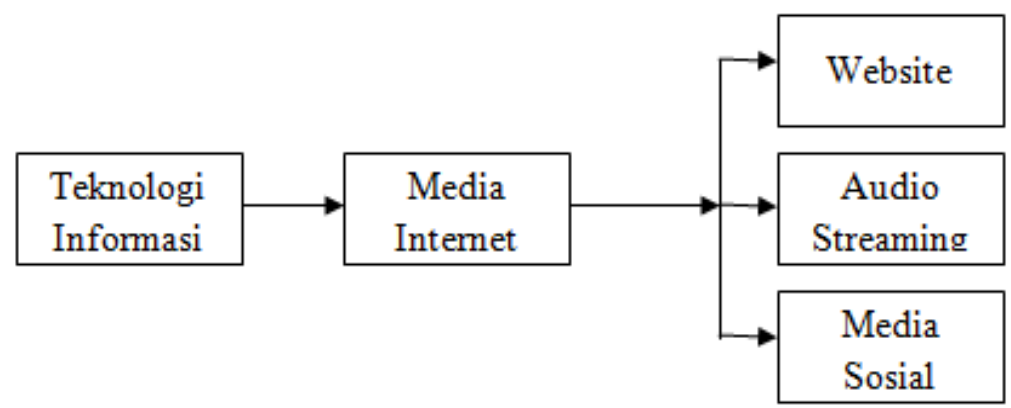

Figure 1: Aspects of Internet Radio Broadcasting Service

Although in some ways, conventional medium send messages from the central transmission point. But the internet medium is more than that. The recipients can click the message instantly from one source to another. Another significant difference from internet to mass media is it's interactive. Internet has the capacity to enable people to communicate, not just a merely receive messages. It can be done in real time. The term of internet radio utilizes the development of Internet technology applications and social media applications. In its development, internet radio developed the penetration in the world. The obtaining of internet-based services needs have also increased. The radio also tries to make a version of broadcasting over the internet. Many radios in Indonesia have not much use this technology because the internet connection is not too good. If you want to use the internet, it should be selected the streaming software that does not use a large bandwidth resource. The setting of encoder should be as small as possible, for example by using 16-24 kbps (mono). Some Internet radio server has a large size, measuring only $136 \mathrm{~KB}$ Shoutcast server. There are several advantages to online radio or internet radio. They are: unlimited broadcast range for internet access, digital sound quality, and do not require any permission as a conventional radio does. 
K-LITE FM using this radio streaming with birate 24, Encoder Type AAC plus, Server Type Icecast, and can be accessed on PC, Android and Black Berry. The listeners just install its application on Google Play or Black Berry World.

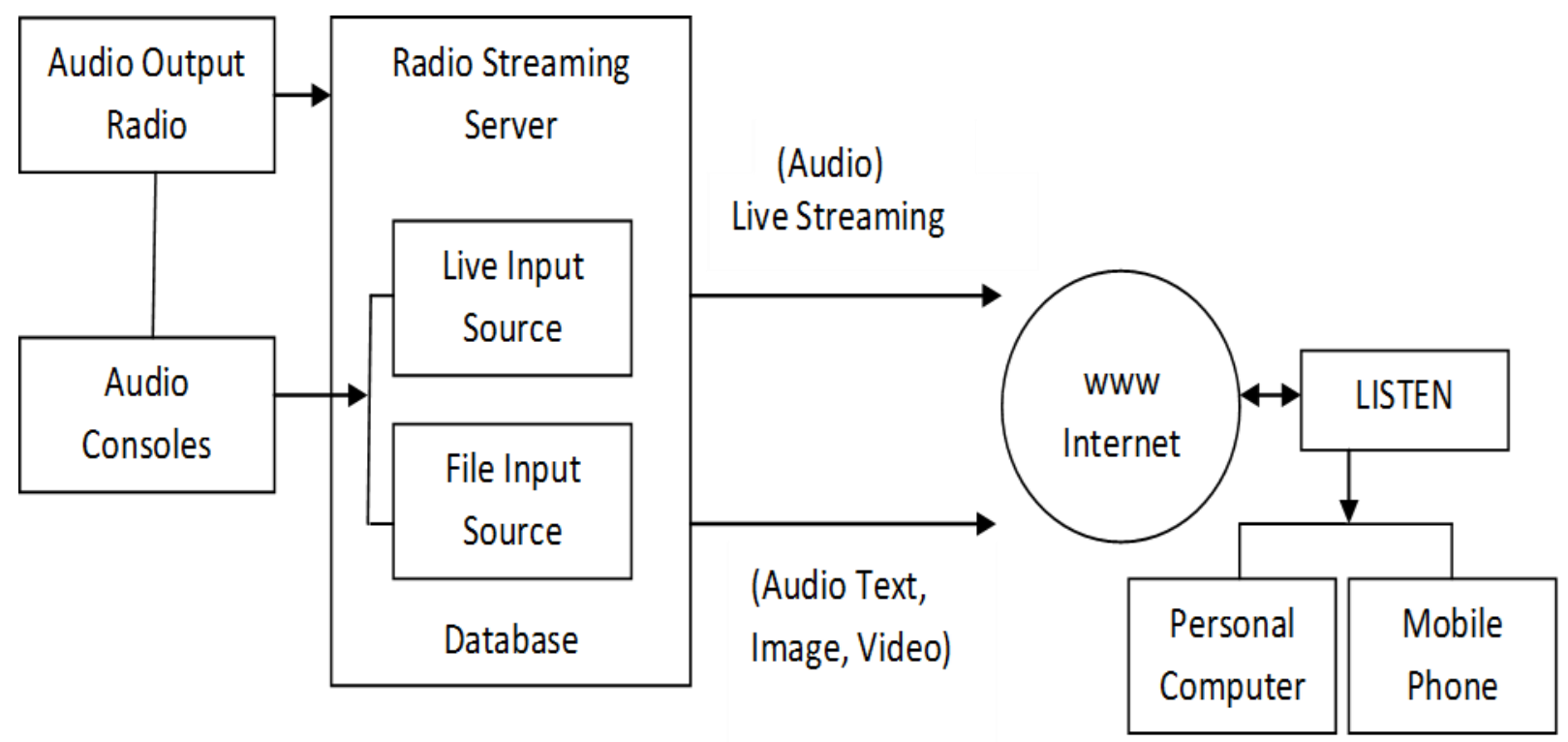

Figure 2: Schematic Radio Broadcast Online

From conventional radio broadcasting communication process, the question raises on how communication through the Internet today. Almost all media observers said that radio broadcasting media is currently undergoing major changes due to the presence of internet media. But based on the research, radio broadcasting in Indonesia today has its progress as well as the frequency of AM broadcasting technologies exist. Suddenly, the trends of frequency modulation (FM) emerged as a new technology in the mid 8os. At that time, many radio broadcasted two frequencies. There are AM and FM. But in the end, AM frequency was closed because the listeners ware getting used to listen to FM. According to the research, the same thing is happened nowadays. The broadcasting radio $\mathrm{FM}$ is on integrating process with the internet because the FM frequency is still exists. In the process of the current radio broadcast communication, conventional radio broadcasting has added other services with internet or online media. The model that found in this study is as follows: 


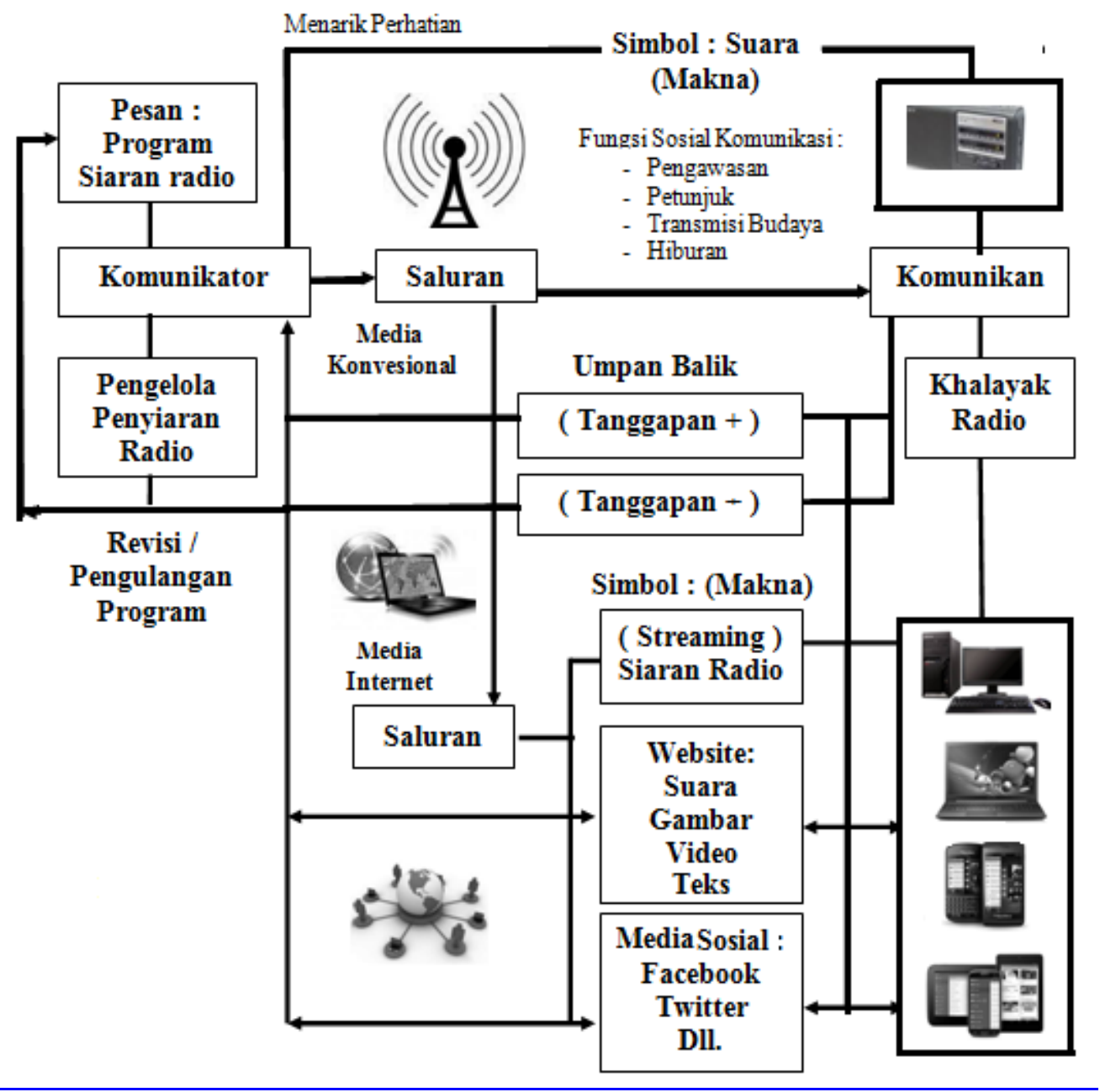

Figure 3: The Process of Broadcast Communications Integration of Conventional and Internet Media

From the above picture, the symbols are the stimuli that generated by communicator and accepted by communicant. Both of them bring meaning to the two parties. But, the radio broadcasting has limitations that only sound can be used as symbols. Although only sound, radio can use the symbol without movement categories. It is called a variety of music and talk radio programming. Meanings are particular symbol and similar response between communicator and communicant in the same contexts of the responses in specific behavioral responses elicited. Certain behavioral responses induced by the symbol (the specific behavioral responses elicited). Sometimes, behavioral responses likely shown by the radio broadcasting communication like thinking, imagining or feeling without realizing physical reaction. The response of behavior 
communicant means that they receive feedback symbols of radio broadcasting. The feedback allows communicators to ascertain whether the symbol has provoked responses from the communicant or listener.

The manager of radio broadcasting as personal or group, tend to allow feedback in helping determined the viability of the program. Positive feedbacks indicate that the purpose of communicators in radio programming has been running well to the program goals. This could be a reference to the program's success. While the negative feedback does not mean that the broadcasted radio program goals gets its failure. As a matter of fact, even negative feedback can be used as a reference to communicators to try again by revising or re-programming. Media shifting from conventional media to new media in the form of online has made the changing in communication patterns. The online media can make a distinct distance to be near and not be hindered by the time. The internet can be accessed at any time for twenty-four hours. No wonder that today, people began to like the internet as the new medium.

In the days before the internet presence, the researchers observed radio communications broadcasting in the form of mass communication. This form of conventional communication medium is still valid today because it is still exist. But in the development of a changing process, it has presented a new technology. It is the internet media communication model one-to-one. Internet has changed communication with several fundamental ways. Basically, conventional mass media model offers a "one-to-many". While the Internet provides additional models: "many-to-one". Currently, there is the development of theory in radio broadcasts through the internet. Theoretically, it is the form of mediated interpersonal communication. It is a special type of interpersonal communication with the term of one to one.

However, the listeners of radio thorugh Internet are still too low when compared to the listeners of conventional media. They still fad or just want to know when they click the streaming radio address. But, it does not last a long time even though the number of Internet users in Indonesia continues to grow. Therefore, it is a challenge for radio broadcasting to accustom the listeners listening to the internet radio.

From the results of this study mentioned that the data of listeners who spend time in listening to radio through the internet required specific research to measure radio broadcasting old habits and time expand of listeners to listen the internet radio in Indonesia. The benefits of Internet radio is the listeners do not bound by geographically. Otherwise, it can be accessed globally. While the benefits of listening to Internet radio is the wider distance of radio coverage that can be heard anywhere and anytime, listened 
to the streaming audio easily and practically with the same quality sound wherever it is, listened to a song or music, and looked for information.

Seeing the phenomenon of social media developments in the world, K-LITE FM uses this condition to collect radio listeners who use social media. It also provides the information of radio broadcasting in text, image or video and other content models, and friendship forum between radio and listeners simultaneously. In this case, the conveying message conveyed tends to be faster as well as the listener or receiver of the message that determines the interaction time. K-LITE FM has a website service, and social media such as Facebook, Twitter, Instagram and Mobile Phone (Black Berry and Android) to interact with the listeners.

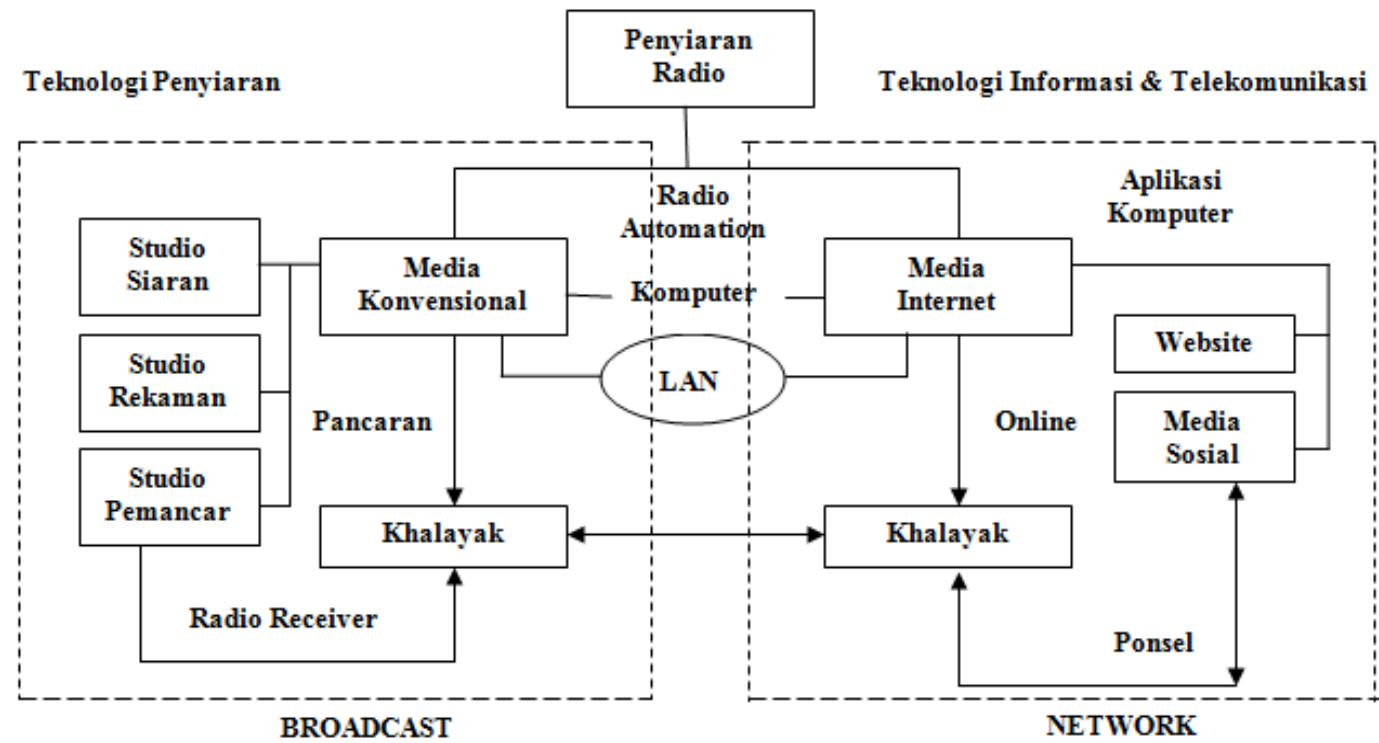

Figure 4: Integration of Conventional Media and Internet in Radio Broadcasting

\section{CONCLUSIONS AND SUGGESTIONS}

Today, radio broadcasting is a multimedia, multi-platform and convergent. It has the sound and image, more interactive, participatory, shareable, hyper-textual, not linear, and convergent. With the integration of radio broadcasting conventional media and the internet, all information can be disseminated through electromagnetic, the medium of internet, reached the network locally and globally. The listeners can receive radio broadcasts through radio receiver (conventional), personal computer (PC) and mobile phone (cellular) locally through internet-based. While globally, the listeners can receive radio broadcasting through personal computer (PC) and mobile phone (cellular) internet-based without any limitation of space and time as long as it has the network to access the Internet. 
PT. Radio Lintas Kontinental (KLITE FM Bandung) do the convergence or integration to broadcast services as operational strategy to deliver broadcast services to become fully broadcasting device. It is not only sound, but equipped with interactive services through text, images, and videos. Interactivity, convergence and computation can lead to a new approach of internet-based radio broadcasting.

The components of radio broadcasting through conventional media and the internet have an important role in managing the business of radio broadcasting, especially in PT. Radio Lintas Kontinental. It is part of a large group of business units YPT (Telkom Education Foundation) From the results of the research findings. The components indicate to support the existing theories. Because of the limitations in this study, however, it needs to be followed up with further studies. So, the existing theory can be tested and verified again. The further research is based on the limitations of this study that focuses on the integration of conventional media broadcasting communication and the internet on private radio broadcasting. Methodologically, the qualitative study and its analysis contain the limitations that measured by the current field data, perception of researchers and informants. This research was conducted by using subjective approach with qualitative data. In order to enrich the theory in the field of radio broadcasting communications, it recommended to add certain studies by using different methods, like theory of activity, exploration of the locality, phenomenological study or critical analysis. The methods should be related to content analysis of internet media communication theory as well as a comprehensive analysis of the radio listeners through internet. The internet radio connected to a radio receiver on the phone/smartphone as well as changes in the radio digital communications in this second media era. 


\section{References}

Friedman dalam Yunis, Manal M., (2010). ICT Maturity as a Driver to Global Competitiveness: a National Level Analysis. International Journal of Accounting and Information Management. Vol.20, 255-281

Keith, Michael C., (2007). The Radio Station - Broadcast, Satellit \& Internet, Sevent Edition. USA: Focal Press.

Lawson-Borders, Gracie, (2008) Media organizations and convergence : case studies of media convergence pioneers. New Jersey: Lawrence Erlbaum Associates, Inc. Publishers

Lister, Martin, Dovey John, Giddings Seth, Grand Iain \& Kelly Kieran, (2009) New Media: A Critical Introduction. New York: Roudledge.

Littlejohn, Steven W., Foss, Karen A., (2009). Encyclopedia Of Communication Theory. California: SAGE Publications,Inc.

McKelvey dalam Yunis, Manal M., (2010). ICT Maturity as a Driver to Global Competitiveness: a National Level Analysis. International Journal of Accounting and Information Management. Vol.20, 255-281.

Medoff, Norman J. \& Kaye, Barbara K., (2011). Electronic Media, Then Now and Later, Second Edition. Burlinton, USA: Focal Press USA.

Mirabito, Michael M. A., Morgenstern, Barbara L., (2004). The New Communications Technologies, Fifth Edition., Burlington, USA: Focal Press.

Prayudha, Harley Harliantara, Munaf, Andy R., (2013). Radio Is Sound Only. Jakarta:Broadcastmagz Publisher.
Schulberg , Pete, (1996). Radio Advertising - The Authoritative Handbook, Second Edition., Lincolnwood, Illinois USA: NTC Business Book.

Severin, Werner J., Tankard Jr., James W., (2001). Teori Komunikasi: Sejarah, Metode, Terapan Di Dalam Media Massa. Jakarta: Prenada Media.

Circum Network inc, management and research consulting, (2006) Conventional radio, Internet radio and satellite radio: a 2005 literature scan.

Sunaryo, (2013). Kamus Istilah Penyiaran Digital. Jakarta: Broadcastmagz Publisher

Turow, Joseph, (2009). Media Today, An Introduction To Mass Communication. New York: Routledge.

Vivian, John, (2008) Teori Komunikasi Massa, edisi Kedelapan (The Media of Mass Communication, $8^{\text {th }}$ edition). (Terj) Tri Wibowo B.S. Jakarta: Kencana Prenada Media Group,

Wahyudi, J.B., (1994) Dasar-Dasar Manajemen Penyiaran. Jakarta: PT. Gramedia Pustaka Utama

Weinberger, Marc G; Campbell, Leland; Brody, Beth, (1994). Effective Radio Advertising. New York:Lexington Books.

Yunis, Manal M., (2010). ICT Maturity as a Driver to Global Competitiveness: a National Level Analysis. International Journal of Accounting and Information Management. Vol.20, 255-281. 
Jurnal komunikasi, Volume 10, Nomor 2, April 2016 